\title{
Junctional and Extrajunctional Glutamate Receptor Channels in Drosophila Embryos and Larvae
}

\author{
Koh-ichi Nishikawa and Yoshiaki Kidokoro \\ Gunma University School of Medicine, Maebashi 371, Japan
}

\begin{abstract}
Glutamate receptor channels in Drosophila embryos and larvae were examined with the patch-clamp technique in various configurations. In the cell-attached mode, only one type of channel was observed in the extrajunctional region at any stages. The burst duration histogram was fit with three exponentials. The burst duration of long component lengthened with increasing glutamate concentration. In excised outside-out patches the unitary channel current was $7.1 \mathrm{pA}$ at $-60 \mathrm{mV}$ and direction of current reversed at zero membrane potential. In contrast, junctional receptor channels had different properties. In the whole-cell configuration, spontaneous synaptic currents with steps on the falling phase were observed. The step amplitudes had two discrete values of 9.4 and $18.5 \mathrm{pA}$ at $-60 \mathrm{mV}$, due to openings of junctional glutamate receptor channels. Synaptic currents changed amplitudes linearly with the membrane potential in the negative potential range but nonlinearly above zero. With $1 \mathrm{~mm}$ glutamate in the bath, synaptic currents were no longer observed. Instead, there were single channel events with the current amplitude varying between 8 and $12 \mathrm{pA}$ at $-60 \mathrm{mV}$. Their long burst duration depended on glutamate concentration indicating that they are glutamate receptor channel events. The extrapolated reversal potential of these channel currents was around $+12 \mathrm{mV}$. These junctional receptor channels were strictly localized at the junction. Our findings suggest that the channel conversion mechanlsm in Drosophlla Is different from that observed in vertebrates. Further close examination of other intermediate steps during neuromuscular junction formation is needed.
\end{abstract}

[Key words: Drosophila, glutamate receptor channel, neuromuscular junction, junctional receptor channel, extrajunctional receptor channel, synaptic current]

During neuromuscular junction formation in vertebrates ACh receptor channels undergo a drastic change in their distribution and channel properties. At early stages, two types of channel, namely, embryonic and adult types, are diffusely distributed over the entire muscle surface. The embryonic type channels are dominant at first and gradually the adult type channels take over the population. These two types of channel have different subunit compositions consisting of $\alpha, \beta, \gamma$, and $\delta$ subunits in the

Received May 22, 1995; revised July 31, 1995; accepted Aug. 2, 1995

This work was supported by grants-in-aid from the Ministry of Education, Science and Culture of Japan and a grant from the Mitsubishi Foundation to Y.K.

Correspondence should be addressed to Dr. Yoshi Kidokoro, Gunma University School of Medicine, 3-39-22 Showa-machi, Maebashi 371, Japan.

Copyright (C) 1995 Society for Neuroscience $0270-6474 / 95 / 157905-11 \$ 05.00 / 0$ embryonic type, and $\alpha, \beta, \epsilon$, and $\delta$ subunits in the adult type (Mishina et al., 1986). They are also functionally different. In cultured Xenopus myocytes the embryonic type channel has a mean open time of about $7 \mathrm{msec}$ and a single channel conductance of about $45 \mathrm{pS}$ while the adult type has a shorter mean open time of about $3 \mathrm{msec}$ and a larger channel conductance of $60 \mathrm{pS}$ (Brehm et al., 1984; Igusa and Kidokoro, 1987; Rohrbough and Kidokoro, 1990). These two types of channel are not segregated, but are homogeneously mixed in the extrajunctional region as well as at the junction. The developmental switch from the embryonic to adult type results in faster kinetics as a population, and faster synaptic current decays (Fischbach and Schuetze, 1980; Kullberg et al., 1985).

In addition to this switch in channel types, the mean open time of each type of channel was found to shorten in cultured Xenopus myocytes (Leonard et al., 1984; Rohrbough and Kidokoro, 1990). A similar change was also found in the tail of Xenopus tadpoles (Owens and Kullberg, 1989). This alteration in the mean open time is relatively large; for example, the mean open time of the embryonic type channel was $25 \mathrm{msec}$ at $27 \mathrm{hr}$ after fertilization and shortened to about $7 \mathrm{msec}$ after $3 \mathrm{~d}$ (Rohrbough and Kidokoro, 1990). Whether a similar change occurs in other species is not yet confirmed.

In cultured embryonic Drosophila myotubes only one type of glutamate receptor channel was found, judging from the unitary amplitude (Kidokoro and Chang, 1991). Similarly, in embryos and larvae one type of channel was observed in the extrajunctional region and the mean burst duration did not change during the period of synapse formation (Kidokoro et al., 1995).

Spontaneous miniature synaptic currents were recorded in muscle cells during early periods of synapse formation (Kidokoro and Nishikawa, 1994). Those synaptic currents often had step-wise changes on the falling phase which were interpreted to be single channel events of junctional glutamate receptor channels. These junctional receptor channels seem to be different from the extrajunctional receptor channels. Namely, their unitary amplitudes are larger than those of the extrajunctional channels.

In this study, we recorded single channel events from junctional as well as extrajunctional glutamate receptor channels in Drosophila embryos and larvae and compared their properties. They were found to be different in various ways. It appears that the nerve modifies channel properties at the subsynaptic membrane and the junctional receptor channels are restricted to the subsynaptic area. We also examined developmental alterations of synaptic currents and channel properties.

A part of these results was briefly presented elsewhere (Kidokoro et al., 1995). 


\section{Materials and Methods}

Fly stock and egg collection. A wild type strain of Drosophila melanogaster, Canton $\mathrm{S}$, was used throughout the study. To obtain timed embryos, eggs were collected every $30 \mathrm{~min}$ from parent flies after damping the first harvest.

Preparation. Fmbryos between 13 and $17 \mathrm{hr}$ after egg laying (AEL) were dissected with a glass needle into "filet" preparations which have been described elsewhere (Broadie and Bate, 1993). Briefly, after removing the egg chorion and vitelline membrane an embryo was cut open at the dorsal midline and spread onto a coverglass surface. Intestines, gonads, fat bodies and trachea were removed and thus the body wall inuscles and ventral nerve cord were exposed. In most cases, Iongitudinal body-wall muscle \#6 was used at the abdominal segment 3 to 5 . Dissection was carried out in the high $\mathrm{Mg}^{2+}$-external solution described below.

As a consequence of cuticle secretion, the external surface of the embryo no longer sticks to the cover glass after around $18 \mathrm{hr}$ AEL. We thus switched to the procedure described previously (Kidokoro and Nishikawa, 1994). Using a pair of sharp needles a part of the rostral end of embryo or larva was removed. One needle was inserted into the open end through the longitudinal axis of the embryo to the caudal end. By pressing the shaft of the other needle along the dorsal midline onto the internal needle, the skin was cut open. The preparation was fixed by a pair of dental floss fibers taped to the glass surface. The distance of two fibers was adjusted with the size of embryos or larvae. All visceral structures were removed and body wall muscles were exposed. The ventral nerve cord was usually removed.

Physiology. Experiments were carried out on an inverted microscope (Diaphot, Nikon, Japan) or on an upright microscope (Axioskop, Carl Zeiss, Germany). The patch-clamp technique was used in various configurations. The patch amplifier was either Axopatch 1B or 1D (Axon Instruments, Foster City, CA). For recording of single-channel events in the cell-attached configuration $20 \mu \mathrm{M}$ to $1 \mathrm{mM}$ L-glutamate dissolved in the external solution was included in the recording electrode. For kinetics and developmental studies in the cell-attached mode, the patch membrane was kept at $+30 \mathrm{mV}$ to increase the driving force for channel currents. For single channel current recordings, embryos and larvae were treated with pronase $(1 \mathrm{mg} / \mathrm{ml}$, actinase, Teikoku-Zoki, Tokyo, Japan) for 1-3 min at room temperature. This treatment seemed to reduce or eliminate desensitization of the receptor and channel activities were observed in practically all patches except in early embryos $(13 \mathrm{hr}$ AEL or earlier ). Over 1000 channel events were captured by a homemade program on the event-triggered basis (A/D board; LabMaster, I'M100 , Scientific Solutions, Solon, $\mathrm{OH})$. Currents were digitized at $50 \mathrm{kHz}$ after filtering at 5 or $10 \mathrm{kHz}$ (four pole Bessel filter). This program captures an event together with a preceding and following baseline of $5 \mathrm{msec}$ regardless of the length of the event. The threshold of the trigger was set a few pA below the half-height of the event.

Extrajunctional glutamate receptor channel events were also recorded in the excised outside-out configuration. In these experiments the preparation was treated with pronase as described above and $100 \mu \mathrm{M}$ or 1 mM glutamate was included in the bath.

For synaptic current recordings and single channel current recordings of junctional receptor channels the whole-cell configuration was used. The internal solution contained $\mathrm{Cs}^{+}$or $\mathrm{K}^{+}$as described below. In these experiments the preparation was treated with collagenase $(1 \mathrm{mg} / \mathrm{ml}$, Worthington, Freehold, NJ) for 2-3 min. The membrane potential was usually held at $-60 \mathrm{mV}$.

All experiments were carried out at room temperature $\left(18-27^{\circ} \mathrm{C}\right)$. To avoid a possible progress of development during recordings experiments were terminated within $30 \mathrm{~min}$ after dissection.

Solutions. The composition of the high $\mathrm{Mg}^{2+}$ external solution was as follows (in $\mathrm{mm}$ ); $\mathrm{NaCl}, 140 ; \mathrm{KCl}, 2 ; \mathrm{MgCl}_{2}, 6$; $\mathrm{HEPES}-\mathrm{NaOH}, 5$ $(\mathrm{pH}, 7.1)$. For spontaneous synaptic current recordings $1 \mathrm{mM} \mathrm{CaCl}_{2}$ was added to this solution. The internal solution for whole cell recordings had the following ionic composition (in $\mathrm{mM}$ ); $\mathrm{CsCl}, 158$; EGTA, 5; HEPES-NaOH, 10; ATP, 2 (pH, 7.1) or $\mathrm{KCl}, 158$; EGTA, 5; HEPES$\mathrm{NaOII}, 10$; ATP, 2 (plI 7.1). The junction potential of the $\mathrm{Cs}^{+}$internal solution was $-5.3 \mathrm{mV}$ and that of the $\mathrm{K}^{+}$internal solution was -4.6 $\mathrm{mV}$. These values were used to correct the membrane potential accordingly.

Biochemicals. Monosodium glutamate, aspartate, and kainate were purchased from Sigma (St Louis, MO). Quisqualate and AMPA $(\alpha-$ amino-3-hydroxy-5-methyl-4-isoxazolpropionic acid) were purchased from Tocris Neuramin (England).

\section{Results}

\section{Extrajunctional glutamate receptor channels}

Glutamate receptor channel events in cell-attached recording. Inwardly directed single-channel currents were readily recorded at any stage later than $14 \mathrm{hr}$ after egg laying (AEL) and at any region of the muscle when the recording patch-clamp electrode contained $1 \mathrm{~mm}$ L-glutamate, although the frequency varied in a wide range $(30-700 / \mathrm{min})$. This is in contrast to the previous observation in cultured embryonic Drosophila myotubes where a majority of patches had channel events at very low frequencies (Chang and Kidokoro, 1995). At least a part of this difference came from the enzyme treatment which we adopted in this study. After the pronase treatment giga-seals were readily formed even in late 1 st instar larvae and channel activities were observed more frequently than without treatment. We suspect in this situation that desensitization of the receptor was reduced or eliminated, because the channel event frequency did not decline during observations of up to $30 \mathrm{~min}$ with $1 \mathrm{~mm}$ glutamate. Furthermore, as will be described below, after the pronase treatment steady inward currents with prominent current fluctuations were observed upon establishment of the whole-cell configuration in the presence of $1 \mathrm{~mm}$ glutamate in the bath, which were never observed without the pronase treatment. However, we did not carry out experiments to confirm this presumption. Concanavalin $\mathrm{A}$ is known to prevent desensitization of the glutamate receptor channel in locust muscle (Mathers and Usherwood, 1977) but does not affect Drosophila glutamate receptor channels (Chang and Kidokoro, unpublished observation).

We believe for the following reasons that these channel events were due to activation of glutamate receptor channels. First, as described below, the long burst duration of these channel events was dependent on the glutamate concentration. Second, when kainate ( $1 \mathrm{~mm}$ ) replaced glutamate in the recording electrode no channel activities were observed. On the other hand, quisqualate (1 mM) activated the receptor channel just as effectively as glutamate but AMPA ( $1 \mathrm{mM})$ did not. These observations are in accord with those in cultured embryonic Drosophila myotubes (Chang and Kidokoro, unpublished observation). Aspartate at $1 \mathrm{~mm}$ did not activate these channels, but at $10 \mathrm{~mm}$ brief openings were infrequently observed. Aspartate also activated receptor channels expressed after injection of Drosophila glutamate receptor cDNA in Xenopus oocytes (Shuster et al., 1991).

Current-voltage relation in cell-attached configuration. Figure $1 A$ depicts sample traces of singlè-channel currents recorded at various membrane potentials in the extrajunctional region of muscle \#6 in an embryo shortly before hatch with $1 \mathrm{~mm}$ glutamate in the recording electrode. There was only one type of channel events in terms of amplitude which was about $9 \mathrm{pA}$ with $30 \mathrm{mV}$ applied in the electrode. The unitary amplitude varied between 7.2 and $11.0 \mathrm{pA}$ from one patch to another. At least a part of this variation is most likely to be due to the variable resting membrane potentials. By changing the potential applied to the electrode the single channel slope conductance was mea sured as $120.7 \pm 7.1 \mathrm{pS}$ (mean $\pm \mathrm{SD} ; n=19$ ) (Fig. 1B). This unitary conductance is smaller than that $(140-170 \mathrm{pS})$ reported by Chang et al. (1994) for the glutamate receptor channel in the absence of external divalent cations. However, in the present experiments $6 \mathrm{~mm} \mathrm{Mg}^{2+}$ was always included in the external solution, and this must have reduced the channel conductance as documented by Chang et al. (1994). On the other hand, this single channel conductance was larger than $81.5 \mathrm{pS}$ at $9^{\circ} \mathrm{C}$ in 
A
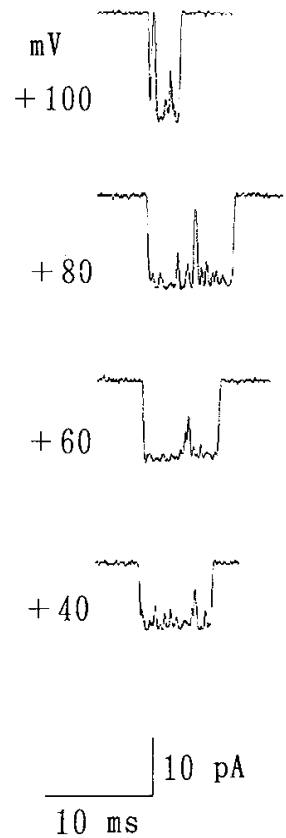

$10 \mathrm{pA}$

$10 \mathrm{~ms}$
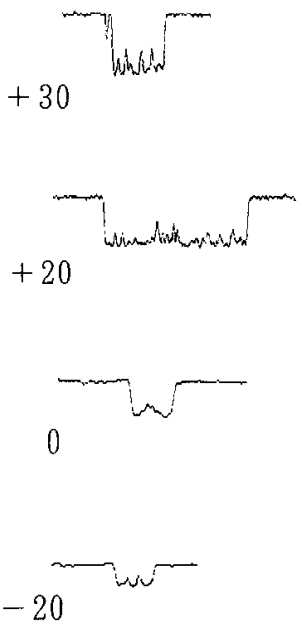

40

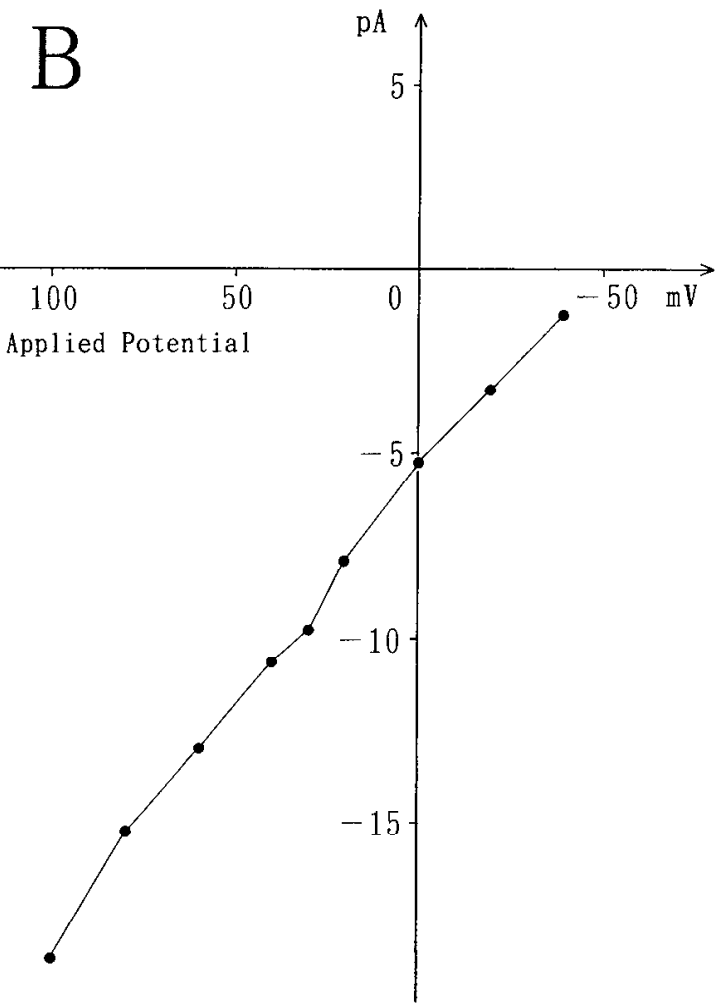

Figure 1. Current-voltage relation of the extrajunctional glutamate receptor channel. $A$, single glutamate receptor channel currents were recorded in the cell-attached configuration at the extrajunctional region of a longitudinal muscle fiber \#6 in a late embryo (20-22 hr AEL). The preparation was treated with pronase for $3 \mathrm{~min}$. The patch electrode contained $1 \mathrm{~mm}$ glutamate in high $\mathrm{Mg}^{2+}$ external solution. The patch membrane potential was varied by applying potentials in the recording pipette. The number at the left of each sample current trace indicates the applied potential at which the current trace was recorded. Current traces were filtered at $2 \mathrm{kHz}$ except traces at $0,-20$, and $-40 \mathrm{mV}$, which were filtered at $1 \mathrm{kHz}$. $B$, Current-voltage relation of the extrajunctional glutamate receptor channel. Note that on the abscissa the applied potential was plotted. The relation was close to linear and the extrapolated zero-current potential was about $-46 \mathrm{mV}$ which indicates the resting membrane potential of this cell. The slope conductance was $124 \mathrm{pS}$.

cultured embryonic Drosophila myotubes (Chang and Kidokoro, unpublished observation). This discrepancy is most likely to be due to the difference in the temperature. The $I-V$ curve was close to linear in the range examined here in the cell-attached configuration. The extrapolated zero-current potential was -46 $\mathrm{mV}$ in the case shown in Figure $1 B$ (average of 19 patches was $-44.9 \pm 6.1 \mathrm{mV}$ ), which indicated the resting membrane potential of this cell because these channel currents reversed the direction at around zero membrane potential as shown below.

Current-voltage relation in outside-out configuration. To control the patch membrane potential more directly we then recorded glutamate receptor channel events in the excised configuration. With $100 \mu \mathrm{M}$ or $1 \mathrm{~mm}$ glutamate in the bath and after the pronase treatment, upon establishment of the whole-cell configuration, steady inward currents of $50-100 \mathrm{pA}$ with prominent fluctuations were observed. In the excised outside-out configuration with the $\mathrm{K}^{+}$internal solution the unitary current amplitude was $7.1 \pm 0.3 \mathrm{pA}(n=6)$ at $-60 \mathrm{mV}$. The $I-V$ curve was also close to linear in the negative potential range and the slope conductance was $114.2 \pm 9.9 \mathrm{pS}(n=5)$, which is not different from those described above in the cell-attached configuration. The extrapolated zero-current potential was $0.3 \pm 4.6 \mathrm{mV}(n=$ 5 ) after correcting for the junction potential. The outward currents were measured successfully only in three patches. The slope conductance in the positive potential range was greater $(275 \pm 90 \mathrm{pS})$. Thus, an outward rectification was observed. The outward current in this condition was carried by $\mathrm{K}^{+}$ions with which this channel seems to have a larger conductance although the permeability ratio $\left(P_{\mathrm{K}} / P_{\mathrm{Na}}\right)$ was close to one indicated by the reversal potential being close to zero. A similar situation was reported in cultured myotubes (Chang et al., 1994). $G_{\mathrm{K}}$ is calculated to be $299 \mathrm{pS}$ whereas $G_{\mathrm{Na}}$ is $140 \mathrm{pS}$ in the absence of divalent cations (calculated from values reported in the Table 3 in Chang et al., 1994). The $P_{\mathrm{K}} / P_{\mathrm{Na}}$ ratio is 1.3 (measured) and 1.01 (calculated; Chang et al., 1994). Thus, these ion permeation properties are essentially the same as those observed in cultured embryonic Drosophila myotubes (Chang et al., 1994).

Kinetics in cell-attached configuration. The open durations of channel events in cell-attached recordings were variable. Some had long open durations with brief closures, showing a bursting behavior, while some others had brief open durations (Fig. 3A). To analyze the channel events further we defined a burst as a series of openings separated by brief closures lasting less than $1 \mathrm{msec}$. Figure $3 B$ shows a burst duration histogram. Three exponentials were needed to adequately fit the histogram. We term them as long, intermediate, and brief burst components as we did previously (Kidokoro and Chang, 1991). We believe that one kind of channel produces these three components because even in patches with very low frequencies of events there were always three components in the burst duration histogram. Previously we have analyzed kinetics of glutamate receptor channels in cultured embryonic Drosophila myotubes (Kidokoro and Chang, 1991; Chang and Kidokoro, unpublished observation). This 

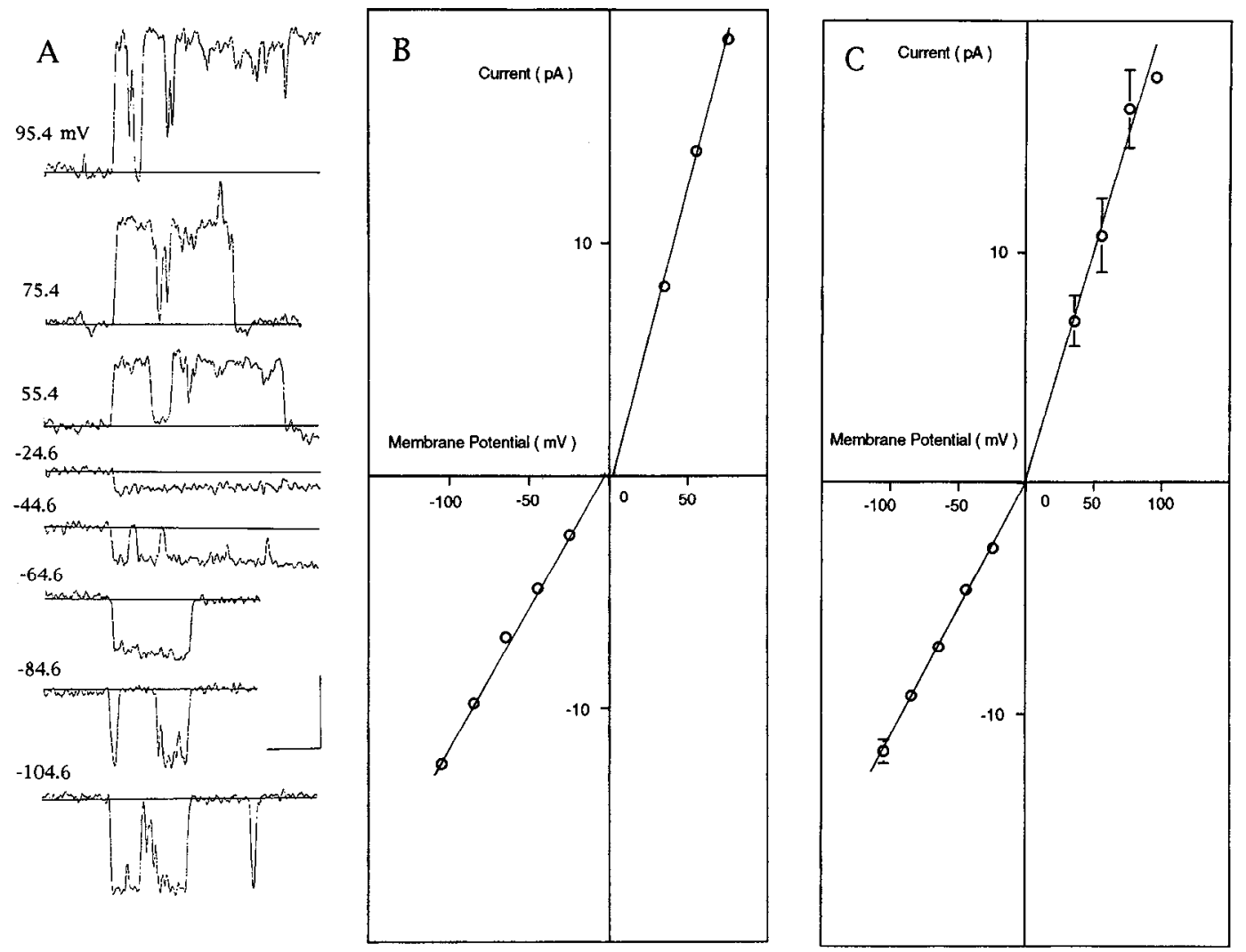

Figure 2. Current-voltage relation of the extrajunctional glutamate receptor channel in an excised outside-out patch. $A$, Sample traces at various membrane potentials. The $\mathrm{K}^{+}$internal solution and normal $\mathrm{Na}^{+}$external solution were used. Numbers on the left indicate patch membrane potentials. Scale bars correspond to $10 \mathrm{pA}$ (vertical bar) and $5 \mathrm{msec}$ (horizontal bar). $B, I-V$ curve of the patch shown in $A$. Straight lines were fitted separately in the negative and positive potential range using the least square method. In the negative range the slope conductance was $122 \mathrm{pS}$ and the $\mathrm{x}$-intercept was $-4.7 \mathrm{mV}$. In the positive range the slope conductance was $265 \mathrm{pS}$ and the $\mathrm{x}$-intercept was $+4.2 \mathrm{mV}$. $C$, Averaged $I-V$ curve obtained from six patches. Straight lines were fitted separately in the negative and positive potential range using the least square method. The slope conductance was $111 \mathrm{pS}$ in the negative range and the $\mathrm{x}$-intercept was $-1 \mathrm{mV}$. In the positive potential range the slope conductance was $202 \mathrm{pS}$ and the $\mathrm{x}$-intercept was $0.3 \mathrm{mV}$. Vertical bars attached to data points indicate SEM. Some were smaller than the size of symbols and a point at $+95.4 \mathrm{mV}$ had only one value.

burst duration histogram is similar to that observed in cultured myotubes. Therefore, we assume that the basic kinetics are the same between these two preparations. According to the previous analysis, the long burst component is the result of activation of the receptor channel with two glutamate molecules and the brief and intermediate burst components are due to one glutamate molecule bound to the receptor.

In accord with this interpretation the long open burst duration was dependent on the glutamate concentration, but the brief and intermediate open components were not (Fig. 4). The mean burst duration of the long open component at limiting low concentrations was $1.9 \mathrm{msec}$, which is smaller than that observed previously $(5.5 \mathrm{msec}$, Chang and Kidokoro, unpublished observation). This discrepancy is most likely to be due to difference in the experimental temperature. Previously experiments were done at low temperature, $9^{\circ} \mathrm{C}$, to enhance time resolution whereas the present experiments were carried out at room temperature. Thus, the extrajunctional glutamate receptor channel was kinctically very similar to that in cultured myotubes.

In the present study the muscles were treated with the pronase for the cell-attached recording but even without the pronase treatment channel events were detected although the event frequency was low. In those cases the channel kinetics were qualitatively similar to those treated with the enzyme.

\section{Junctional glutamate receptor channels}

As mentioned earlier we found that there was only one type of channel with a unitary conductance of about $120 \mathrm{pS}$ in the extrajunctional region throughout the period of synapse formation. Meanwhile we noted previously that miniature endplate currents had steps on the falling phase which were considered to be channel events underling synaptic currents (Kidokoro and Nishikawa, 1994). These junctional channels seemed to be different from those in the extrajunctional region in terms of unitary amplitude. Here we examined further the junctional glutamate receptor channel. The junctional glutamate receptor channel was studied only in the whole-cell configuration without the pronase treatment. We could not detect junctional glutamate receptor channels in the extrajunctional region in the cell-attached configuration.

Multiple steps on the falling phase of synaptic currents. In the whole-cell configuration spontaneous synaptic currents were recorded (Fig. 5A). On the falling phase there were steps as described previously (Kidokoro and Nishikawa, 1994). There were at least two discrete steps as shown in Figure $5 B$, at 9.4 $\pm 1.2 \mathrm{pA}(n=7$, number of cells examined) (first step) and at $18.5 \pm 2.3 \mathrm{pA}(n=8)$ (second step). In some cells, a third peak was noted at about $23 \mathrm{pA}(n=2)$. At the same time, sponta- 


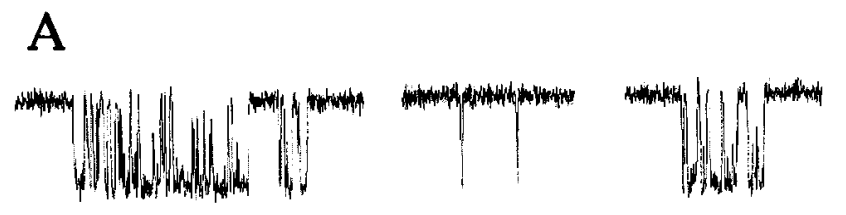

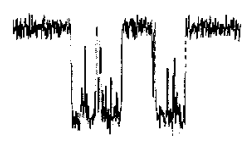
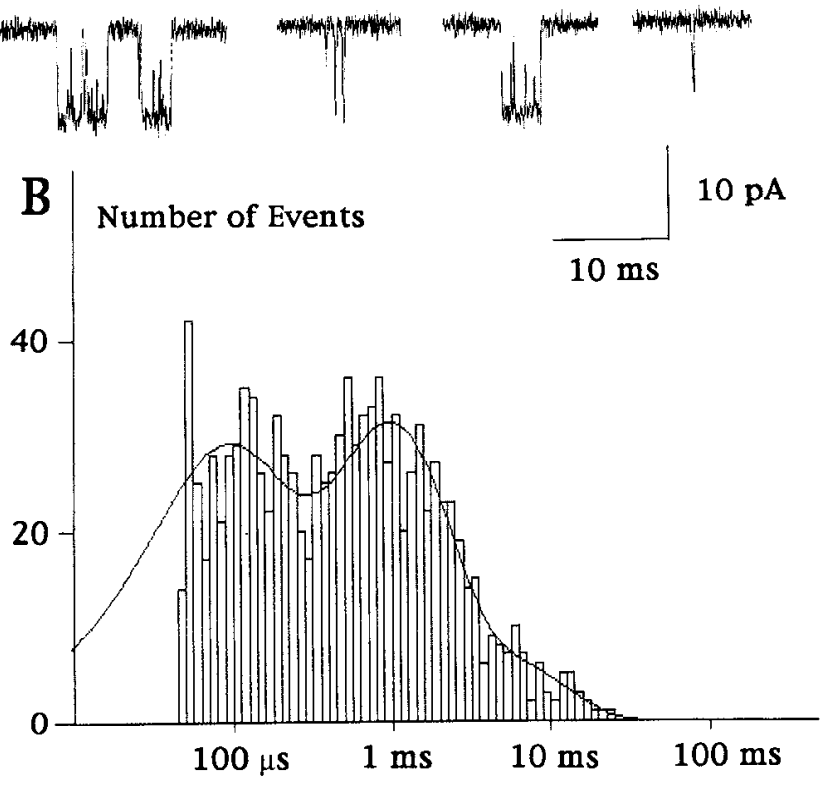

\section{Burst Duration in Logarithm}

Figure 3. Kinetics of the extrajunctional glutamate receptor channel activated with $1 \mathrm{~mm}$ glutamate in the cell-attached configuration. The inside of the recording pipette was kept at $+30 \mathrm{mV}$ to increase the unitary current amplitude. $A$, Sample traces. The current was filtered at $5 \mathrm{kHz}$. B, Burst duration histogram. The burst was defined as a series of openings separated by brief closures lasting less than $1 \mathrm{msec}$. The burst duration was plotted lngarithmically on the abscissa against the number of events on the ordinate. Three exponentials were fit with the maximum likelihood method. The time constants were $4.9 \mathrm{msec}, 900$ $\mu \mathrm{sec}$, and $69 \mu \mathrm{sec}$ for the long, intermediate, and brief burst component, respectively. The fractional amplitudes were $0.11,0.5$, and 0.39 .

neous single-channel events were also observed (events marked with dots in Fig. 5A), the amplitude of which $(9.2 \pm 1.6 \mathrm{pA}, n$ $=6$ ) was similar to that of the first step on the falling phase of synaptic currents, suggesting that these single-channel events were due to activation of junctional glutamate receptor channels. However, we have never seen single channel events with the amplitude corresponding to the second step, that is, $18.5 \mathrm{pA}$.

As previously pointed out (Kidokoro and Nishikawa, 1994), the amplitude of the second step is close to twice that of the first step (Fig. 5B). The amplitude of these steps varied from cell to cell and there was a good correlation between the amplitudes with a slope close to two (slope $=1.9$, correlation coefficient $=0.907$ significant at 0.005 , Fig. $5 C$ ), suggesting that the second steps are due to two channels simultaneously being open. However, the falling phase of the second step was just as fast as the first one (arrow in Fig. 5 $\Lambda$ ). Therefore, it looked as if two channels closed simultaneously.

We have not observed steps on the falling phase of synaptic currents with the amplitude corresponding to that of extrajunctional receptor channels (about $7 \mathrm{pA}$ ). But if extrajunctional receptor channels at the junction desensitized rapidly, we might not see them as discrete steps on the falling phase. Therefore,

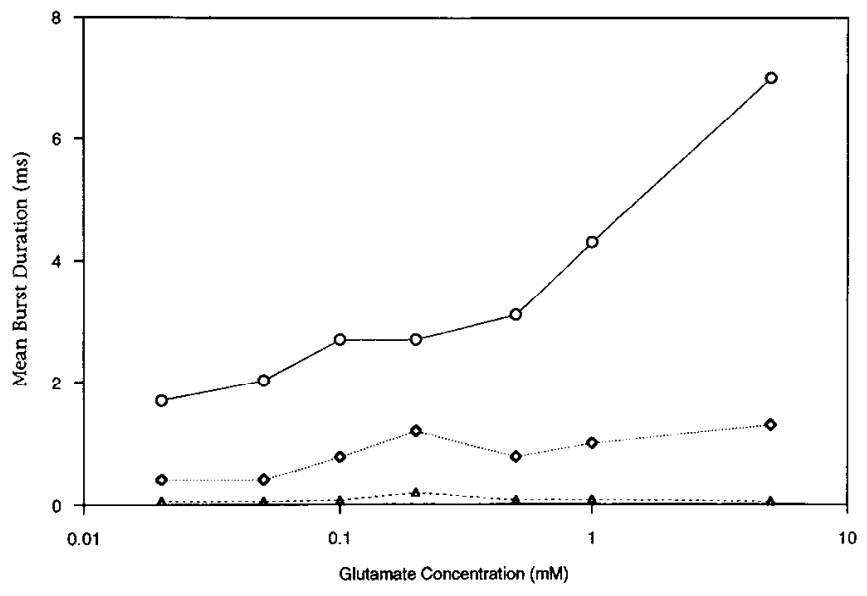

Figure 4. Glutamate concentration dependency of burst durations of extrajunctional glutamate receptor channels recorded in the cell-attached configuration. Open circles, long open component. Diamonds, Intermediate open component. Triangles, Brief open component.

the possibility remains that there are extrajunctional glutamate receptor channels at the junction.

Current-voltage relations of synaptic currents. When the membrane potential was varied the mean amplitude of spontaneous synaptic currents changed almost linearly in the range between -60 and $-10 \mathrm{mV}$ but behaved nonlinearly above zero (inward rectification in the potential range below the reversal potential and outward rectification above it). The current reversed its polarity at the potential above $+10 \mathrm{mV}$ (Fig. $6 B$; the reversal potential estimated by linear interpolation was $+23.3+$ $4.2 \mathrm{mV}, n=3$ ). In this case major cations in the internal solution were $\mathrm{Cs}^{+}$. However, since similar $I-V$ curves have been reported by Broadie and Bate (1993) for nerve-evoked synaptic currents and glutamate-induced currents with the internal solution containing $\mathrm{K}^{+}$, this nonlinear $I-V$ curve is not peculiar to internal $\mathrm{Cs}^{+}$ions. As described above, the extrajunctional glutamate receptor channels have $I-V$ curves close to linear even in the positive membrane potential range with internal $\mathrm{K}^{+}$solution and showcd outward rectification. Therefore, the nonlinear $I-V$ curve of synaptic currents and the positive reversal potential suggest that the glutamate receptor channel at the junction differs in ion permeation properties from the extrajunctional receptor channel. However, this nonlinearity could be due to voltage-dependent kinetics of the junctional glutamate receptor channel.

In crayfish muscles, Onodera and Takeuchi (1978) reported that the reversal potential of excitatory synaptic current was $+23.8 \mathrm{mV}$, which is close to what we have observed here. Also in Drosophila embryos Broadie and Bate (1993) reported $I-V$ curves which indicate the reversal potential to be positive (Fig. $8 A$ in their paper). However, the $I-V$ curves for Drosophila 3rd instar larvae, reported by Jan and Jan (1976), show reversal potentials close to zero under various ionic condition's. At this moment we do not have any explanation for this discrepancy.

Single glutamate receptor channel events recorded in the whole-cell configuration. To further verify the origin of single channel events in the whole-cell configuration, we applied various concentrations of glutamate in the bath without the pronase treatment while recording single channel currents in the wholecell configuration. With $1 \mathrm{~mm}$ glutamate in the bath, spontaneous synaptic currents were no longer observed but single channel events with an amplitude of about $10 \mathrm{pA}$ at $-60 \mathrm{mV}$ were seen 

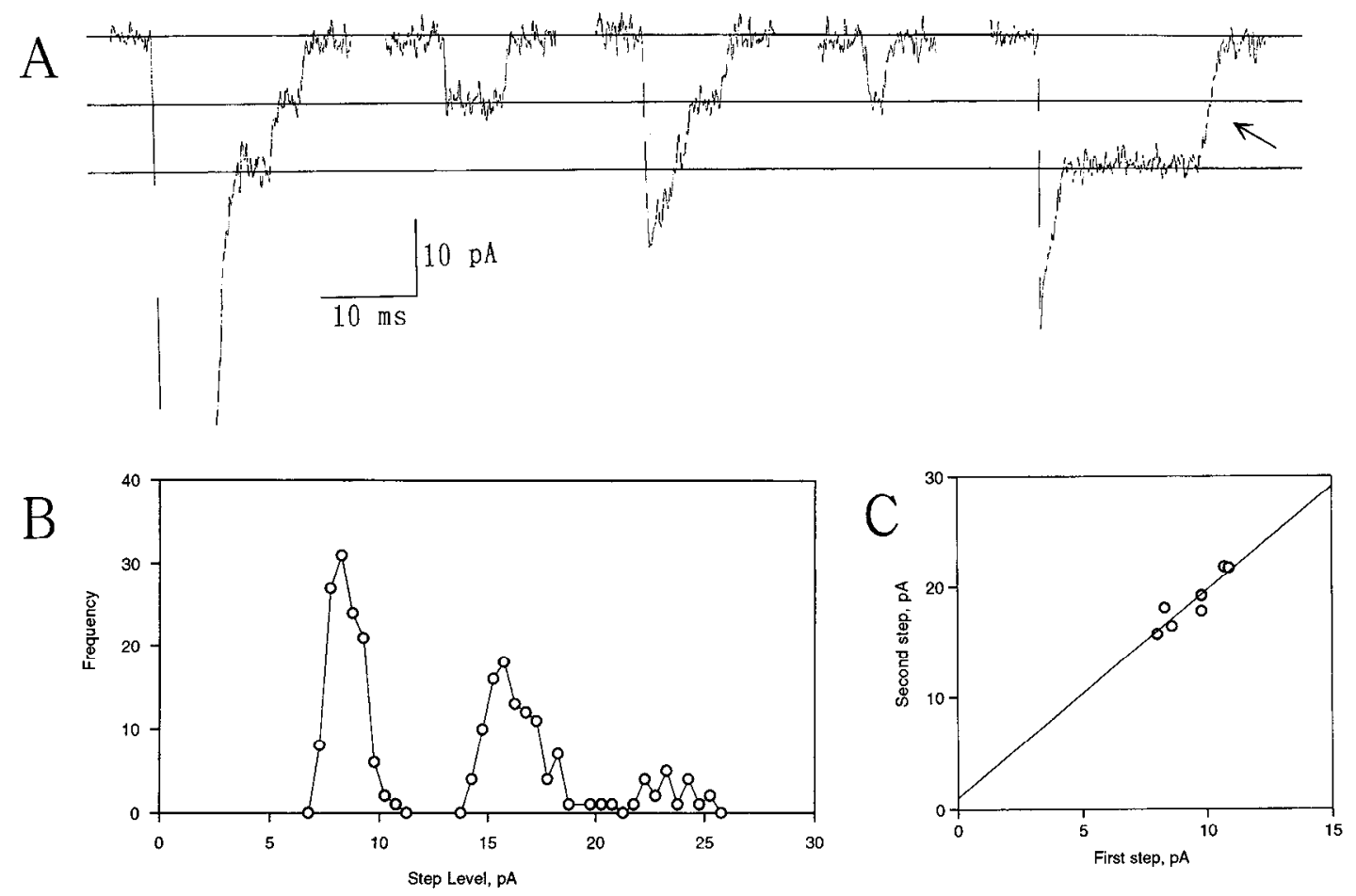

Figure 5. Multiple steps on the falling phase of miniature endplate currents. A, Sample traces of synaptic currents and single channel currents (marked with dots). These currents were recorded in the whole-cell configuration with the internal $\mathrm{Cs}^{+}$solution from muscle \#6 of an embryo of 15.5-16.0 hr AEL. The holding potential was $-60 \mathrm{mV}$. The first trace from the left was truncated at the peak. The smaller step was at $8.0 \mathrm{pA}$ and the larger one at $15.7 \mathrm{pA}$. The single channel current amplitude was $7.8 \mathrm{pA}$. Three horizontal lines indicate the base line, the first step level and the second step level from top to bottom. An arrow indicates the falling phase of the large step. $B$, A frequency histogram of step levels measured in one cell. Horizontal levels lasting at least a few ms were measured on the falling phase of synaptic currents. Single channel events were not included. These data were obtained with the internal $\mathrm{K}^{+}$solution from a muscle fiber \#6 of a first instar larva. $C$, Correlation between the first and second step level. The straight line is a least-square regression line. The slope is 1.9 and the correlation coefficient is 0.907.

Figure 6. Voltage dependency of synaptic currents. $A$, Sample traces of miniature endplate currents recorded from an embryo at 16.5-17.0 $\mathrm{hr}$ AEL. The internal $\mathrm{Cs}^{+}$solution was uscd. Numbers at the left of each trace are the membrane potential, after correcting for the junction potential, at which the current was recorded. $B$, The mean amplitude of miniature endplate currents is plotted against the membrane potential at which currents were recorded. Vertical bars attached to some data points are SEM. Others had SEM smaller than the width of the symbols.
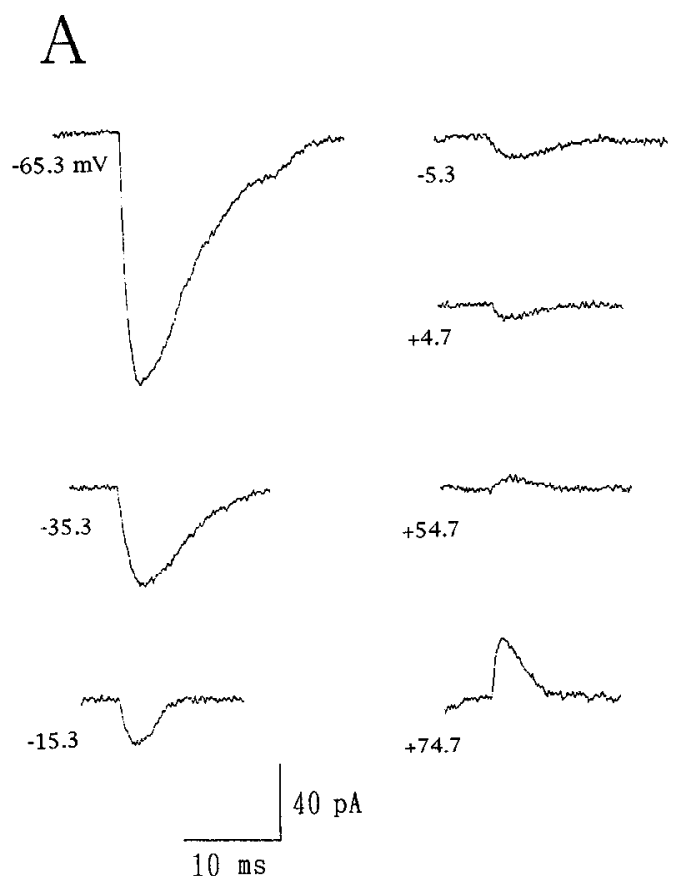


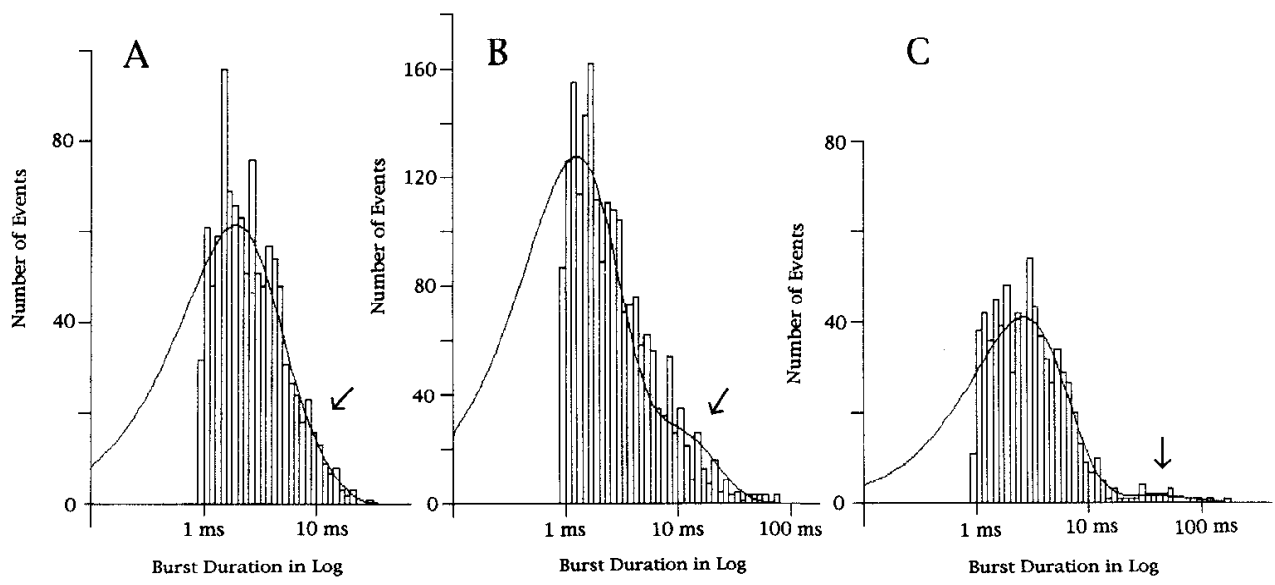

Figure 7. Burst duration histograms for junctional glutamate receptor channels recorded in the whole-cell configuration. The membrane potential was held at $-60 \mathrm{mV}$. Since events were infrequent and it was difficult to ohtain enough events in one cell, data from three to five cells at a given concentration of glutamate were combined. Two exponentials were used to fit the histograms in the range longer than 1 msec using the maximum likelihood method. $A, 100 \mu \mathrm{M}$. The mean burst durations of the long and intermediate component were $4.3 \mathrm{msec}$ and $1.6 \mathrm{msec}$, respectively. $B$, 1 $\mathrm{mm}$. The mean burst durations of the long and intermediate component were $8.4 \mathrm{msec}$ and $1.2 \mathrm{msec}$, respectively. $C, 5 \mathrm{~mm}$. The mean burst durations of the long and intermediate component were $34.5 \mathrm{msec}$ and $2.6 \mathrm{msec}$, respectively. Arrows indicate the long component.

infrequently. This observation is in accord with previous reports (Jan and Jan, 1976; Kidokoro and Nishikawa, 1994). This observation was interpreted to mean that synaptic currents were not observed because a majority of junctional glutamate receptors were desensitized by exogenously applied glutamate. Single-channel events were probably from receptor channels which temporarily recovered from desensitization. As for extrajunctional glutamate receptor channels almost all of them were probably desensitized as we have hardly observed single channel events with the amplitude of about $7 \mathrm{pA}$ at $-60 \mathrm{mV}$ expected for the extrajunctional receptor channel. Furthermore, we observed no steady inward currents upon establishment of the whole-cell configuration even in the presence of $1 \mathrm{~mm}$ glutamate in the bath. This is in contrast to the situation after the pronase treatment as described earlier.

Since channel events were infrequent, it was difficult to record many single-channel events from one cell under this condition. By combining those channel events recorded from several cells, a burst duration histogram was constructed (Fig. 7B). Two exponentials were used to fit the histogram. These probably cor-

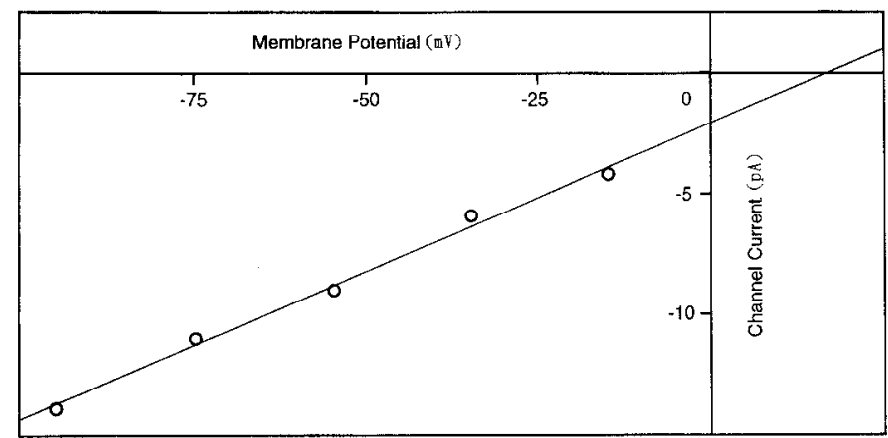

Figure 8. Current-voltage relation of the single junctional glutamate receptor channel. The receptor channel was activated with $1 \mathrm{mM}$ glutamate in the bath. The channel currents were recorded from muscle \#6 in an embryo at about $16 \mathrm{hr}$ AEL in the whole-cell configuration with the $\mathrm{Cs}^{+}$internal solution. Data were obtained from five patches. The straight line was fitted with the least square method. The slope conductance was $122 \mathrm{pS}$ and the extrapolated zero-current potential was +6.6 $\mathrm{mV}$. The SEMs were smaller than the width of symbols. respond to the long and intermediate open components in the burst duration histogram of the extrajunctional receptor channel. The brief component was not recorded, either because the large capacitance of the cell prevented the recording of brief events, or because the junctional glutamate receptor channel did not have the brief component. The long and intermediate burst component had time constants of $8.4 \mathrm{msec}$ and $1.2 \mathrm{msec}$, respectively, with $1 \mathrm{~mm}$ glutamate in the bath. Much longer bursts were observed with $5 \mathrm{~mm}$ glutamate in the bath as seen in the histogram (34.5 msec, for long burst duration and $2.6 \mathrm{msec}$ for intermediate burst duration; Fig. 7C) whereas with $100 \mu \mathrm{M}$ glutamate the long burst durations were briefer $(4.3 \mathrm{msec}$, for long burst duration and $1.6 \mathrm{msec}$ for intermediate burst duration, Fig. $7 A$ ). Thus, the long burst duration of these single-channel events was dependent on the glutamate concentration in the bath. Thereforc, wc considered that these single-channel events re corded in the whole-cell configuration were due to activation of glutamate receptor channels.

Having established that these channel events in the whole-cell configuration are due to activation of glutamate receptor channels, we further characterized these channel events. The unitary amplitude of these junctional single channel currents ranged between 8.0 and $12.1 \mathrm{pA}(10.5 \pm 1.3 \mathrm{pA}, n=15)$ at $-60 \mathrm{mV}$. With cell-attached recording we would expect these junctional channels to have a unitary amplitude of more than $12 \mathrm{pA}$ with $30 \mathrm{mV}$ applied in the recording electrode assuming the resting potential of about $-50 \mathrm{mV}$ (the reversal potential of these junctional channel currents is more positive than $10 \mathrm{mV}$ as described below). In order to record junctional receptor channel currents in the cell-attached configuration, we extensively searched for such large channel events around perijunctional region but failed. Therefore, we concluded that these junctional receptor channels were strictly localized at the junction where we could not access with the patch electrode.

When the membrane potential was varied the amplitude of the glutamate receptor channel currents changed almost linearly in the negative potential range with a slope conductance of 115.4 $\pm 5.2 \mathrm{pS}(n=5)$ but the extrapolated zero-current potential was positive, approximately $8 \mathrm{mV}$ (Fig. $8 ;+12.3 \pm 3.1 \mathrm{mV}, n=$ 5 ). This observation suggests that these single channel currents 
were originating from junctional glutamate receptor channel because as described earlier synaptic currents became zero at the potential above $+10 \mathrm{mV}$ (Fig. 6B). This suggestion is in accord with the fact that the amplitude of these channel events was similar to that of the smaller steps on the falling phase of synaptic currents and single channel events in the absence of external glutamate (Fig. 5A).

\section{Developmental changes of synaptic currents and channel properties}

Miniature endplate currents. We defined synaptic currents as those which had a fast rising phase followed by a relatively slower decay phase. This definition eliminated the infrequently observed single channel events. As shown previously (Kidokoro and Nishikawa, 1994), spontaneous synaptic currents recorded in this experimental condition were not blocked by tetrodotoxin and were considered to be miniature endplate currents, which were presumably due to spontaneous release of transmitter from individual synaptic vesicles (Katz, 1969). Figure $9 A$ depicts developmental changes of the mean amplitude of miniature endplate currents. The mean amplitude increased gradually between 16 and $22 \mathrm{hr}$ AEL. Before $16 \mathrm{hr}$ AEL, only single channel events were recorded as described below. After $16 \mathrm{hr}$, single channel cvents were obscrved in-betwecn miniature cndplate currents as shown in Figure $5 A$. These could be due to nonquantal release of transmitter (Katz and Miledi, 1977) or to quantal release of transmitter at regions of low receptor density.

Time course of synaptic currents. The synaptic currents had a fast rise time (time interval between 10 and $90 \%$ of the peak amplitude) of about $1.0 \mathrm{msec}$ or less and the decay phase of synaptic currents fit reasonably well with one exponential (time constant, 5-8 msec; Kidokoro and Nishikawa, 1994). In Figure $9, B$ and $C$, the decay time constant and rise time were plotted against hours AEL. There is a gradual increase in the decay time constant (Fig. 9B) without a change in the rise time (Fig. 9C).

In the frog it has been shown that the decay time constant of synaptic currents is determined by the mean open time of the junctional $\mathrm{ACh}$ receptor channel in the presence of acetylcholinesterase (Anderson and Stevens, 1973). Since there is no corresponding enzyme to degrade released glutamate in the insect neuromuscular junction, it is not clear what determines the decay time constant of synaptic currents.

We found that the decay time constant of synaptic currents increased during the period of synapse formation. This is in contrast to what found in Xenopus neuromuscular junctions (Owens and Kullberg, 1989; Rohrbough and Kidokoro, 1990). The shortening of the decay time constant in Xenopus embryos and tadpoles is the result of a shift of channel population from embryonic type to adult type, and changes in channel kinetics within each type of channel. In Drosophila we have found only one type of junctional glutamate receptor channel in terms of unitary amplitude. Therefore, we suggest that the increase in the decay time constant found in this study is due to a change in the kinetics of the junctional receptor channel or due to changes in the ultra structure which impedes transmitter diffusion from the synaptic cleft.

Extrajunctional glutamate receptor channels. According to Broadie and Bate (1993), the density of extrajunctional receptor channel decreases as receptors accumulate to the nerve contact region between 13.5 and $16 \mathrm{hr}$ AEL. If that is the case, we would expect less frequent encounters with patches exhibiting channel events and less frequent channel events in each patch. The prep-
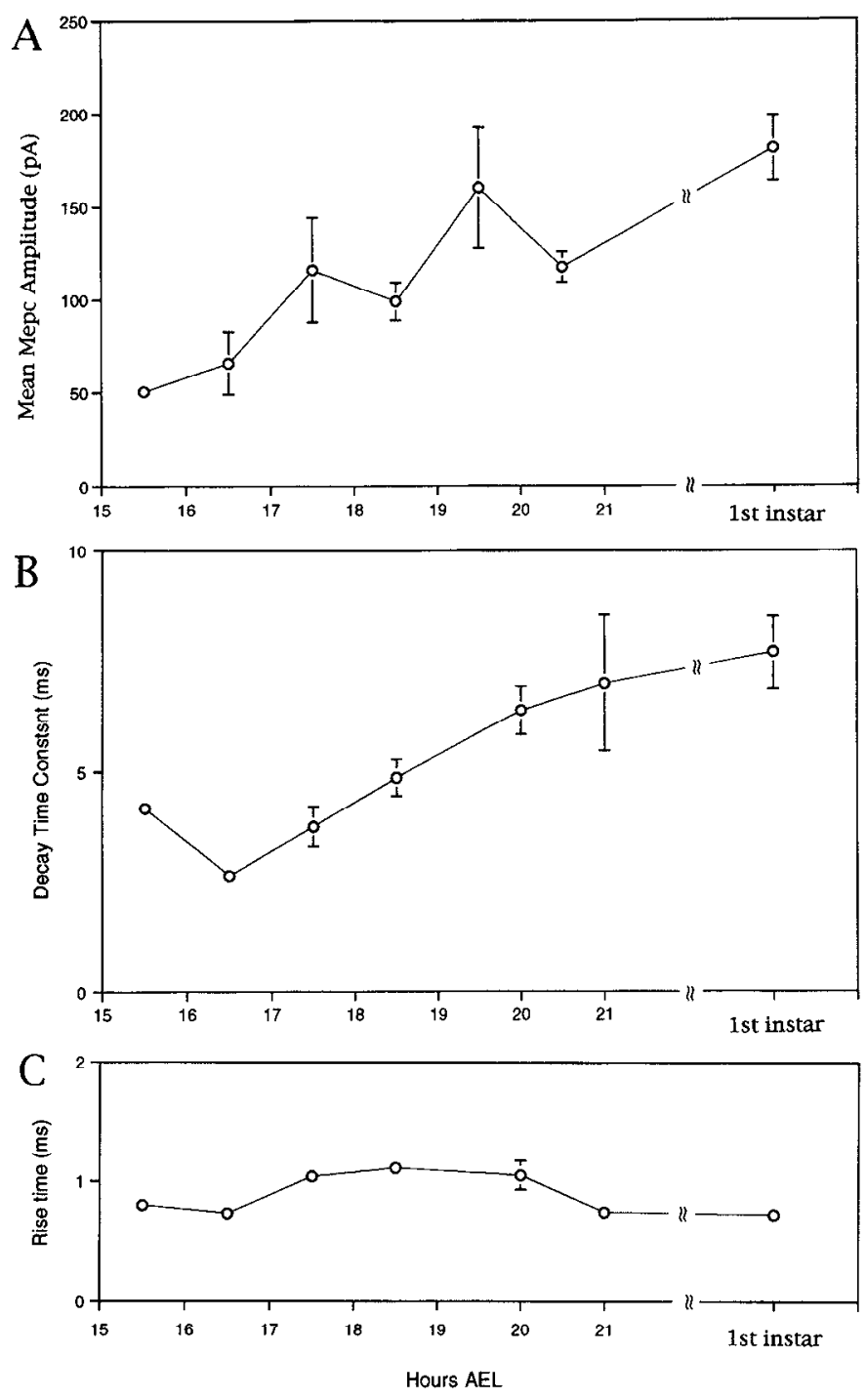

Figure 9. Developmental changes of miniature endplate current properties. The membrane potential was held at $-60 \mathrm{mV}$. A, The mean amplitude was plotted against hours AFI. $R$, The decay time constant was plotted against hours AEL. Several synaptic currents with rise times $1 \mathrm{msec}$ or less were averaged and a single exponential was fitted with the least square method. Since the decay time constant tended to be longer when the amplitude of synaptic current was larger (Kidokoro and Nishikawa, 1994), synaptic currents with amplitudes between 100 and $200 \mathrm{pA}$ were used. $C$, The rise time was plotted against hours AEL. The rise time was defined as the time interval between 10 and $90 \%$ of amplitude. When the recording electrode was clogged the rise time became slower. Therefore, only cases with a clean rupture of patch membrane were adopted for these measurements.

aration was treated with pronase and single-channel events were recorded in the cell-attached configuration in the extrajunctional region. In Figure 10A the frequencies of channel events in patches were plotted against developmental time. At $13 \mathrm{hr}$ AEL, no channel events were recorded. This observation is in accord with the result of experiment in which sensitivities to iontophoretically applied glutamate were measured (Broadie and Bate, 1993). Once channel events appeared at 14-15 hr AEL and reached a plateau at 15-16 hr AEL, there was no tendency for the channel event frequency to decline. Furthermore, patches made at any region of muscle almost always exhibited channel events even in late first instar larvae. Thus, we believe that re- 


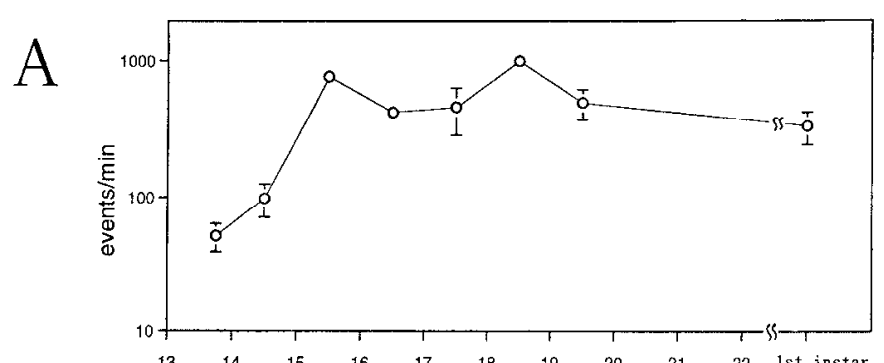

$\mathrm{B}$
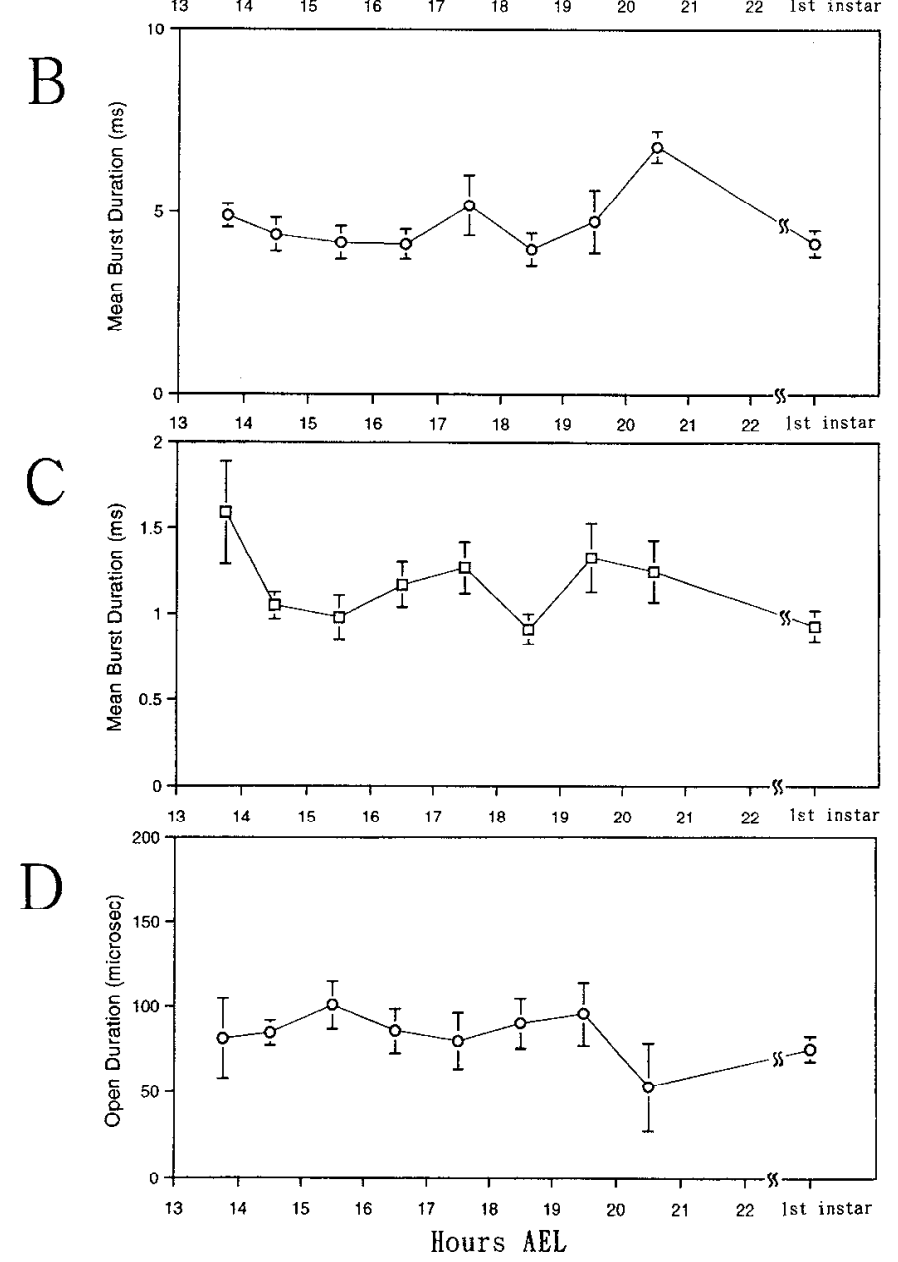

Figure 10. Developmental changes of extrajunctional glutamate receptor channels. The channel currents were recorded in the cell-attached configuration with $1 \mathrm{~mm}$ glutamate and $30 \mathrm{mV}$ was applied in the electrode. $A$, The frequency of channel events was plotted against hour AEL. The frequency was measured by counting events which crossed the threshold of $8 \mathrm{pA}$. $B$, The mean burst duration of the long open component versus hours AEL. $C$, The intermediate open component. $D$, The brief open component.

ceptor channels were present in the extrajunctional region even at late stages but they were not detected previously with iontophoretic application of glutamate (Broadie and Bate, 1992). We will discuss later a possible explanation for this discrepancy.

It has been shown in Xenopus that the burst duration of the $\mathrm{ACh}$ receptor channel in the extrajunctional region shortens during the period of synapse formation (Leonard et al., 1988; Owens and Kullberg, 1989; Rohrbough and Kidokoro, 1990). In Drosophila embryos and larvae we measured the burst durations of glutamate receptor channels at various developmental stages. As shown in Figure $10 B-D$, there was no change in the burst durations from the time of initial channel emergence at $13.5 \mathrm{hr}$ AEL to late 1 st instar larvae. We concluded that the kinetics of the extrajunctional glutamate receptor channel did not change during the period examined in this experiment.

Single-channel events before appearance of spontaneous synaptic currents. Between 13 and $16 \mathrm{hr}$ AEL spontaneous synaptic currents were not observed. Meanwhile, Broadie and Bate (1993) reported that nerve-evoked synaptic currents were already recorded during this period. Therefore, we tested whether we could observe junctional glutamate receptor channel events at this early stage.

Shortly after establishment of the whole cell configuration in early embryos (13.5-14 hr AEL) large single-channel events with an amplitude of 15.0 to $21.5 \mathrm{pA}$ at $-60 \mathrm{mV}$ were often observed in the absence of exogenous glutamate (Fig. 11, events marked with dots). These channel events usually disappeared in a few minutes. Furthermore, in the absence of extcrnal $\mathrm{Ca}^{2+}$ these large-amplitude channel events were extremely rare. Therefore, we did not considered these events to be due to activation of glutamate receptor channels. Although much less frequent, channel events with an amplitude of about $10 \mathrm{pA}(9.7-$ $10.5 \mathrm{pA}$ ) at $-60 \mathrm{mV}$ were also observed. The frequency of channel events with this amplitude was much greater when 1 mM glutamate was included in the bath. Therefore, we considered these channel events to be due to activation of junctional glutamate receptor channels.

Thus, we confirmed that junctional glutamate receptor channels were already in the subsynaptic membrane at this early stage of synapse formation when no miniature endplate currents were observed.

\section{Discussion}

We found that in embryonic and larval muscles the junctional receptor channel was different from the extrajunctional receptor channel in the following aspects. (1) The mean unitary current amplitude at $-60 \mathrm{mV}$ was $10.5 \pm 1.3 \mathrm{pA}$ (mean $\pm \mathrm{SD}, n=$ 15 ) in the junctional receptor channel while it was $7.1 \pm 0.3 \mathrm{pA}$ $(n=6)$ in the extrajunctional receptor channel. (2) The $I-V$ curve was inward-rectifying in the potential range below the reversal potential and outward-rectifying above in the former and outward-rectifying in the latter. (3) The reversal potential was more positive than $10 \mathrm{mV}$ in the former but was close to zero in the latter. (4) Without pronase treatment desensitization was prominent in the latter while less so in the former. (5) The former was not found in the extrajunctional region with the cellattached configuration while the latter was found anywhere at any slages laler than $14 \mathrm{hr}$ AEL. Thus, we conclude that these two types of channels are distinctly different. Table 1 summarizes the differences.

In the crayfish neuromuscular junction, kainate enhances the glutamate action at the extrajunctional area but depresses it at the junction (Onodera and Takeuchi, 1980). Thus, junctional and extrajunctional glutamate receptors could also be different pharmacologically.

\section{Extrajunctional glutamate receptor channels}

Glutamate receptor channels remain in the extrajunctional region during synapse formation. The channel event frequency stayed the same from the time shortly after initial emergence at $14 \mathrm{hr}$ AEL up to the stage of 1st instar larvae. Admittedly, the frequency of channel event is not a good measure of channel density as it is affected by other factors, such as channel kinetics 
Figure 11. Single channel events in muscle \#6 in an embryo at 13.5-14.0 hr AEL. Left three events with dot marks had distinctly larger amplitudes than two events on the right. Larger amplitude events tended to occur shortly after establishment of the whole-cell configuration and gradually subsided. The amplitude ranged from cell to cell between 15.0 and $21.5 \mathrm{pA}(1 \% .6 \pm 2.6$ $\mathrm{pA}, n=6$ ). The smaller amplitude events were infrequent throughout the recording period. The amplitude ranged between 9.7 and $10.5 \mathrm{pA}(10.1 \pm 0.4$ pA, $n=4)$.

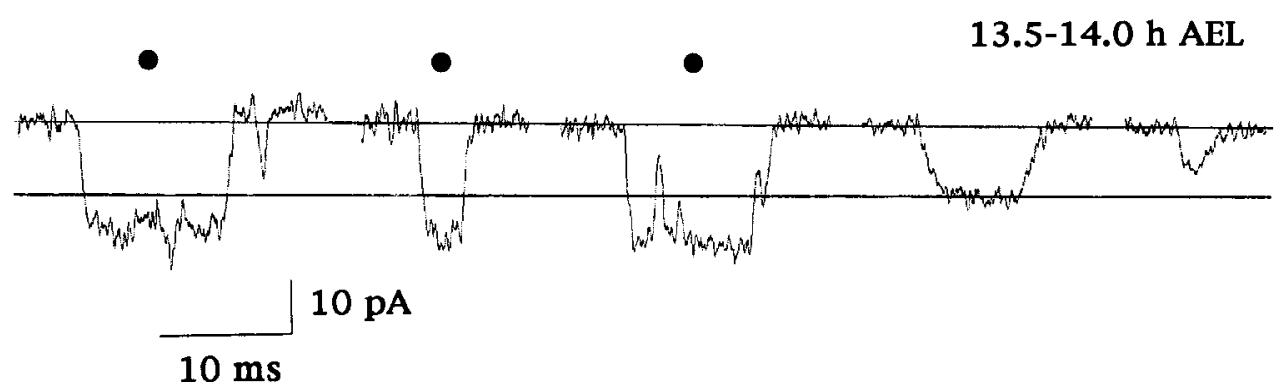

and dcscnsitization. However, as we have demonstrated above the channel kinetics stayed the same throughout the period examined, and the effect of desensitization was minimized by the pronase treatment. Therefore, we tentatively suggest that the channel density in the extrajunctional areas remained unchanged during this period.

This conclusion is in contrast to the report by Broadie and Bate (1993) in which they studied the distribution of sensitivities to iontophoretically applied glutamate. At $15 \mathrm{hr}$ AEL, they did not detect glutamate sensitivities in the extrajunctional region, and concluded that all receptor channels were accumulated at the junction. We offer another plausible interpretation for their observation. Glutamate receptors are known to desensitize rapidly (Dudel et al., 1992). Therefore, leakage of glutamate from the iontophoretic electrode might have completely desensitized the receptors in the extrajunctional region at $15 \mathrm{hr}$ AEL or later. Since they observed high sensitivities at the junction, desensitization properties of junctional receptors might be different from those in the extrajunctional region. For cell-attached channel current recordings, we treated embryos and larvae with pronase which may have reduced or eliminated desensitization. Without this enzyme treatment, the percentage of patches which showed channel activities was low. This interpretation was supported by the observation that with $1 \mathrm{~mm}$ glutamate in the bath and without the pronase treatment, there was no steady inward currents upon establishment of the whole-cell configuration. In contrast, after the treatment, steady inward currents with large fluctuations were seen in the presence of $1 \mathrm{~mm}$ glutamate. When a patch was excised in the outside-out configuration single channel currents were observed which had a reversal potential at around zero, indicating that these currents were originating from the extrajunctional receptor channel.

In Xenopus nerve-muscle cultures, the receptor channel density in the extrajunctional region was shown also unchanged even after accumulation of receptors at the junction (Gruener and Kidokoro, 1982; Kidokoro and Gruener, 1982).

Extrajunctional receptor channels are the same as those in cultured myotubes. Previously we have studied glutamate recep- tor channels in cultured embryonic myotubes (Kidokoro and Chang, 1991; Chang et al., 1994; Chang and Kidokoro, unpublished observation). The glutamate receptor channels in the extrajunctional region were similar in the following properties to those in cultured myotubes; (1) The unitary conductance was $120.7 \mathrm{pS}$ in the extrajunctional receptor channel at room temperature and in the presence of $6 \mathrm{mM} \mathrm{Mg}^{2+}$. While that in cultured myotubes was $81.5 \mathrm{pS}$ at $9^{\circ} \mathrm{C}$ in the presence of $6 \mathrm{~mm}$ $\mathrm{Mg}^{2+}$ and $157.6 \mathrm{pS}$ at room temperature and in the absence of divalent cations. It is known that presence of divalent cations in the external solution and low temperature reduce the unitary conductance. Therefore, these values can be considered as comparable. (2) The reversal potential was close to zero in various ionic conditions in cultured myotubes and in the bi-ionic condition ( $\mathrm{Na}^{+}$external and $\mathrm{K}^{+}$internal solution) in the extrajunctional receptor channel. (3) The $I-V$ curve for the extrajunctional receptor channel showed an outward rectification in the bi-ionic condition $\left(\mathrm{Na}^{+}\right.$external and $\mathrm{K}^{+}$internal solution) and an inward rectification for cultured myotubes in an opposite ion distribution ( $\mathrm{K}^{+}$external and $\mathrm{Na}^{+}$internal solution). Therefore, it appears that in both types $\mathrm{G}_{\mathrm{K}+}$ is greater than $\mathrm{G}_{\mathrm{Na}^{+}}$. Furthermore, (4) in both types the burst duration histograms were adequately fit with three exponentials and the mean burst duration of the long open component increased with the glutamate concentration while those of the intermediate and brief open components did not.

In all, ion permeation and kinetic properties of the extrajunctional receptor channel are essentially the same as those of receptor channels in cultured myotubes.

\section{Junctional glutamate receptor channels}

When $1 \mathrm{~mm}$ glutamate was included in the bath solution without pronase treatment, large amplitude channel events (about $10 \mathrm{pA}$ at $-60 \mathrm{mV}$ ) were observed. The mean burst duration changed with glutamate concentration in the bath. Therefore, we considered that these were due to activation of glutamate receptor channels. This amplitude is similar to the small step on the falling phase of synaptic currents, and single channel events with similar amplitudes were observed between spontaneous synaptic

Table 1. Summary of differences in junctional and extrajunctional channels

\begin{tabular}{|c|c|c|c|c|c|}
\hline $\begin{array}{l}\text { Glutamate receptor } \\
\text { channel }\end{array}$ & $I-V$ relation & Reversal potential & $\begin{array}{l}\text { Single } \\
\text { channel } \\
\text { conductance }\end{array}$ & $\begin{array}{l}\text { Unitary } \\
\text { current } \\
\text { amplitude } \\
\text { at }-60 \mathrm{mV}\end{array}$ & $\begin{array}{l}\text { Desensiti- } \\
\text { zation }\end{array}$ \\
\hline Junctional & Nonlinear in the positive potential range (?) & More positive than $+10 \mathrm{mV}(?)$ & $115.4 \mathrm{pS}$ & $10.5 \mathrm{pA}$ & + \\
\hline Extrajunctional & Weak outward rectification & Approximately zero & $120.7 \mathrm{pS}$ & $7.1 \mathrm{pA}$ & ++ \\
\hline
\end{tabular}


currents. The $I-V$ curve for these channel currents was close to linear in the negative potential range but the extrapolated zerocurrent potential was $+12.3 \mathrm{mV}$. In accord with this observation, we found that the synaptic currents had linear $I-V$ relation in the negative potential range and became nonlinear in the positive potentials. The interpolated reversal potential of the synaptic current was more positive than $+10 \mathrm{mV}$. Therefore, we concluded that in the presence of glutamate in the bath, junctional glutamate receptor channels were activated which had different channel properties from those of the extrajunctional glutamate receptor channel. We think that a great majority of extrajunctional glutamate receptors were desensitized under this experimental condition as discussed above.

Receptor localization at the junction. The mean amplitude of miniature endplate currents increased gradually between $16 \mathrm{hr}$ AEL and the 1 st instar larval stage. Previously we found no change in the amplitude between first and sccond instar larvae (Kidokoro and Nishikawa, 1994). Thus, it seems that this increase in the mean amplitude is completed at the 1st instar larval stage. This change is analogous to that observed in Xenopus nerve-muscle cultures where the miniature endplate potential amplitude increased as $\mathrm{ACh}$ receptors accumulated at the nerve contact area (Anderson and Cohen, 1977; Kidokoro et al., 1980). Therefore, we suggest that the glutamate receptor density in the subsynaptic membrane increased during this period. When miniature endplate currents were first detected at around $16 \mathrm{hr}$ AEL the mean amplitude was about $50 \mathrm{pA}$ which indicated that only five channels on average were activated upon vesicular release of glutamate. Functional glutamate receptor channels were already detected at $13.5 \mathrm{hr}$ AEL. During the period between 13.5 and $15 \mathrm{hr}$ AEL, spontaneous synaptic currents were not observed but occasionally single channel events with the amplitude of about $10 \mathrm{pA}$ at $-60 \mathrm{mV}$ were observed.

We have never encountered junctional receptor channels in the cell-attached configuration even though we purposely aimed at the junctional area, suggesting that the junctional receptor channels are strictly localized at the junction. When a growth cone contacts the muscle membrane it is likely that the subsynaptic membrane at first contains extrajunctional receptor channels and the nerve modifies thosc channels to the junctional typc. This modification process seems to occur quickly within a short time after nerve contact as we have recorded junctional single channel events in embryos at 13.5-14.0 hr AEL. Judging from the amplitude of the step on the falling phase of synaptic currents, it seems that all junctional channels have junctional channel properties.

In contrast, in Xenopus muscles adult type $\mathrm{ACh}$ receptor channels (junctional type) were found in the extrajunctional region mixed with embryonic receptor channels (extrajunctional type) (Owens and Kullberg, 1989). Meanwhile, synaptic currents decay with two exponentials, indicating that both types of channels also reside in the subsynaptic membrane (Kullberg et al., 1985). The segregation of junctional receptor channels at the junction occurs later as the receptor density in the extrajunctional region decreases. Thus, the strategy to achieve localization of junctional receptor channels at the junction is clearly different between these two species. Further close examination of other intermediate steps during synapse formation is needed.

\section{References}

Anderson CR, Stevens CF (1973) Voltage clamp analysis of acetylcholine produced end-plate current fluctuations at frog neuromuscular junction. J Physiol (Lond) 235:655-691.
Anderson MJ, Cohen MW (1977) Nerve-induced and spontaneous redistribution of acetylcholine receptors on cultured muscle cells. J Physiol (Lond) 268:757-773.

Brchm P, Kidokoro Y, Moody-Corbett (1984) Acetylcholine receptor channel properties during development of Xenopus muscle cells in culture. J Physiol (Lond) 357:203-217.

Broadie K, Bate M (1993) Development of the embryonic neuromuscular synapse of Drosophila melanogaster. J Neurosci 13:144-166.

Chang H, Ciani S, Kidokoro Y (1994) Ion permeation properties of the glutamate receptor channel in cultured embryonic Drosophila myotubes. J Physiol (Lond) 476:1-16.

Dudel J, Franke C, Hatt H (1992) Rapid activation and desensitization of transmitter-liganded receptor channels by pulses of agonists. In: Ion channels, Vol 3 (Narahashi T, ed), pp 207-260. New York: Plenum.

Fischbach GD, Schuetze SM (1980) A post-natal decrease in acetylcholine channel open time at rat endplates. J Physiol (Lond) 303: $125-137$.

Gruener R, Kidokoro Y (1982) Acetylcholine sensitivity of innervated and noninnervated Xenopus muscle cells in culture. Dev Biol 91:8692.

Igusa Y, Kidokoro Y (1987) Two types of acetylcholine receptor channels in developing Xenopus muscle cells in culture: further kinetic studies. J Physiol (Lond) 389:271-300.

Jan LY, Jan YN (1976) L-Glutamate as an excitatory transmitter at the Drosophila larval neuromuscular junction. J Physiol (Lond) 292:215236.

Katz B (1969) The release of neural transmitter substances. Springfield, IL: Charles C. Thomas.

Katz B, Miledi R (1977) Transmitter leakage from nerve endings. Proc R Soc Lond [Biol] 196:59-72.

Kidokoro Y, Chang H (1991) Kinetic properties of glutamate receptor channels in embryonic Drosophila myotubes in culture. Biomed Res 12(Suppl):73-76.

Kidokoro Y, Gruener R (1982) Distribution and density of $\alpha$-bungarotoxin binding sites in innervated and noninnervated Xenopus muscle cells in culture. Dev Biol 91:78-85.

Kidokoro Y, Nishikawa K (1994) Miniature endplate currents at the newly formed neuromuscular junction in Drosophila embryos and larvae. Neurosci Res 19:143-154.

Kidokoro Y, Anderson MJ, Gruener R (1980) Changes in synaptic potential properties during acetylcholine receptor accumulation and neurospecific interactions in Xenopus nerve-muscle cell culture. Dev Biol 78:464-483.

Kidokoro Y, Nishikawa K, Yoshihara M (1995) Glutamate receptor channels and synapse formation in embryonic Drosophila muscles. In: Basic neuroscience in invertebrates, in press.

Kullberg R, Kasprzak H (1985) Gating kinetics of nonjunctional acetylcholine receptor channels in developing Xenopus muscle. J Neurosci 5:970-976.

Kullberg R, Brehm P, Steinbach JH (1981) Nonjunctional acetylcholine receptor channel open time decreases during development. Nature 289:411-413.

Kullberg R, Owens JL, Vickers J (1985) Development of synaptic currents in immobilized muscle of Xenopus laevis. J Physiol (Lond) 364: $57-68$.

Leonard RJ, Nakajima S, Nakajima Y, Takahashi T (1984) Differential development of two classes of acetylcholine receptors in Xenopus muscle in culture. Science 226:55-57.

Mathers DA, Usherwood PNR (1977) Concanavalin A blocks desensitization of glutanlate receptors on insect muscle fibres. Nature 259 . $409-411$.

Mishina M, Takai T, Imoto K, Noda M, Takahashi T, Numa S, Methfessel C, Sakmann B (1986) Molecular distinction between fetal and adult forms of muscle acetylcholine receptor. Nature 321:406-411.

Onodera K, Takeuchi A (1978) Effects of membrane potential and temperature on the excitatory post-synaptic current in the crayfish muscle. J Physiol (Lond) 276:183-192.

Onodera K, Takeuchi A (1980) Distribution and pharmacological properties of synaptic and extrasynaptic glutamate receptors on crayfish muscle. J Physiol (Lond) 306:233-250.

Owens JL, Kullberg R (1989) In vivo development of nicotinic acetylcholine receptor channels in Xenopus myotomal muscle. J Neurosci 9:1014-1028.

Rohrbough J, Kidokoro Y (1990) Changes in kinetics of acetylcholine receptor channels after initial expression in Xenopus myocyte culture. J Physiol (Lond) 425:245-269. 